\title{
EXPERIMENTAL INVESTIGATION ON THE POINT LOAD STRENGTH OF RED-BED SILTSTONE WITH DIFFERENT SHAPES
}

\author{
Huayan YAO ${ }^{1)}$, Ling DAI ${ }^{1)}$, Guang LIU ${ }^{1)}$ *, Yun JIA ${ }^{2)}$ and Xiaolu YUAN ${ }^{3)}$ \\ 1) School of Civil Engineering, Hefei University of Technology, Hefei, 230009, China \\ 2) LaMcube, University of Lille, Cite Scientifique, 59655, Villeneuved'Ascq, France \\ ${ }^{3)}$ Key Laboratory of Geological Hazards on Three Gorges Reservoir Area (China Three Gorges University), \\ Ministry of Education, Yichang, 443002, China \\ *Corresponding author's e-mail: guang_liu@hfut.edu.cn
}

\begin{tabular}{l} 
ARTICLE INFO \\
\hline Received 1 January 2020 \\
Accepted 8 December 2020 \\
Available online 17 December 2020 \\
\hline
\end{tabular}

\section{Keywords:}

Red-bed siltstone

Point load strength

Uniaxial compressive strength

Shape effect

Correction

Failure mode

\begin{abstract}
The point load test is an indirect method to estimate the uniaxial compressive strength (UCS) of rock. In order to investigate the influence of the shape effect on the point load test strength of the siltstone in the Red Stratum, a series of point load tests were carried out on siltstone specimens with different shapes (cylinders, blocks, irregular specimens). The results show that the point load strength index of red-bed siltstone specimens with different shapes exhibits significant dispersion. As long as being corrected, the specimen shape has no significant effect on the point load strength index $\mathrm{I}_{\mathrm{s}(50)}$. The average value of $\mathrm{I}_{\mathrm{s}(50)}$ from formula correction is consistent with the value obtained by the graphical method with all different shape specimens in consideration. An empirical relation is proposed for the estimation of UCS by the point load strength $\mathrm{I}_{\mathrm{S}(50)}$. The red-bed siltstone specimens under the point load test are broken into two pieces or three pieces, but the former failure is dominant.
\end{abstract}

\section{INTRODUCTION}

Uniaxial compressive strength (UCS) of rock is one of the crucial parameters for stability evaluation of geotechnical or geological engineering. Uniaxial compression tests for rocks require standard cylinder specimens (e.g., cylinder specimen with diameter $50 \mathrm{~mm}$ and high $100 \mathrm{~mm}$ ). Hence, the process of sample preparation is complex and time-consuming (Emir and Beyhan, 2016). Especially when soft rock is used to prepare standard rock samples for a uniaxial compression test, initial damage is often produced on rock samples, or the sample is broken or disintegrated in the process of core drilling (Eberhardt et al., 1999; Peng et al., 2019; Wang and Cai, 2018). In addition, the UCS test is challenging to carry out in the field. Therefore, point load test (PLT) proposed by Brock and Franklin (1972) have been widely accepted (Bieniawski, 1975; Kahraman, 2001; Li and Wong, 2013; Singh et al., 2012; Wong et al., 2017; Akbay and Altindag, 2018; 2020), which can be applied to different types of rocks without cutting and grinding either in the field or in the laboratory due to its portable testing equipment.

The point load strength index (PLSI) $\mathrm{I}_{\mathrm{s}}$ can be determined on rock specimens in the form of either cylindrical cores, blocks, or irregular specimens. According to some researchers (Broch and Franklin,1972; Turk and Dearman,1985; Pabek, 1992;
Koohmishi and Palassi, 2016; Masoumi et al., 2018), the sample size and shape have significant influences on the $I_{s}$ values. In order to obtain a consistent strength index for the same rocks, International Society for Rock Mechanics and Rock Engineering (ISRM, 1985) suggest correcting the $I_{S}$ values to a standard size of $50 \mathrm{~mm}$, which is called size corrected PLSI, $\mathrm{I}_{\mathrm{s}(50) \text {. }}$ However, the comparative analysis and reliability of the $I_{S(50)}$ from different shape samples have not been thoroughly studied.

The reliable relation between the $\mathrm{I}_{\mathrm{S}(50)}$ and UCS is also a concern of many researchers (Agustawijaya, 2007; Hawkins and Olver, 1986; Li and Wong, 2013; Singh et al., 2012; Tsiambaos and Sabatakakis, 2004; Wong et al., 2017; Yin et al., 2017). Some representative results have been applied in practice. However, these results showing the relation of $\mathrm{I}_{\mathrm{s}(50)}$ and UCS depend strongly on the rock types (Yin et al., 2017). It is particularly desired to conduct extensive experiments on different types of rocks to establish general empirical relationships.

Red strata are widespread in China, for example, the Three Gorges Reservoir area, the southern mountainous region of Anhui Province, etc., where geological hazards such as landslides frequently occur (Wang et al., 2004; Zhang et al., 2015). Red strata are continental sedimentary rocks composed of alternating red mudstone, sandstone and siltstone. It is 


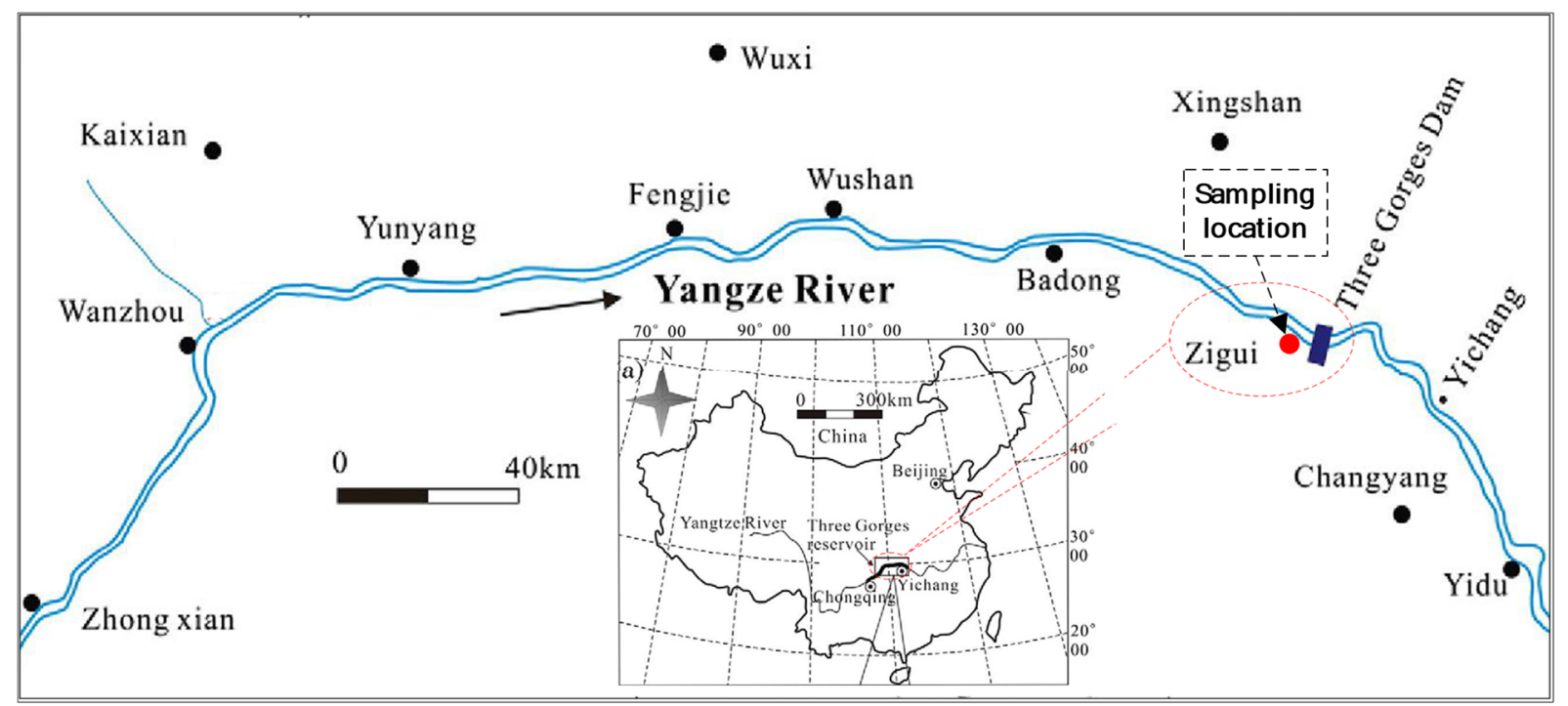

Fig. 1 A sketch map for the sampling location.

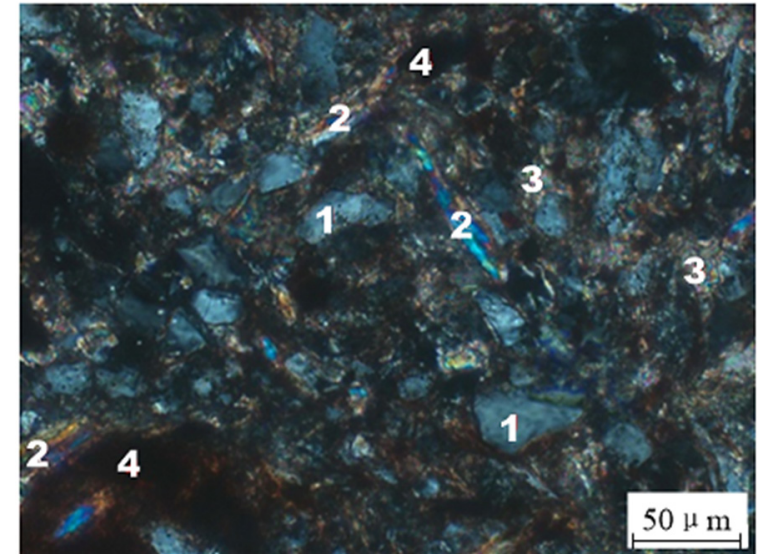

(a) Crossed-polarized image

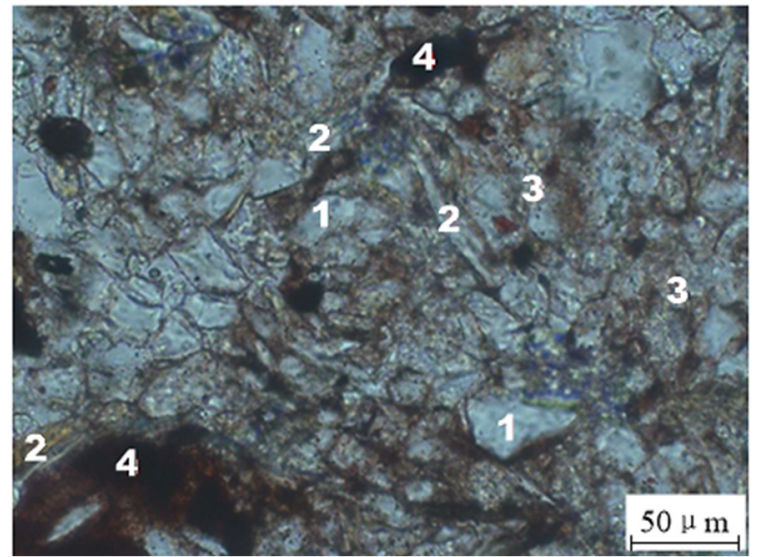

(b) Plane-polarized image

Fig. 2 Images obtained by a polarizing microscope, 1- quartz, 2-mica, 3-calcite, 4-iron mineral.

an important basis for the prevention and control of geological hazards to obtain the strength properties of this kind of red-bed rocks through a large number of tests. Therefore, it is essential to adopt an efficient and simple test method, such as the point load test. The purpose of this paper is mainly to discuss the influences of shapes of rock samples on point load strength index and to obtain a reliable estimation on $\mathrm{I}_{\mathrm{s}(50)}$ and UCS of red-bed siltstone in the Three Gorges Reservoir area.

\section{ROCK MATERIALS AND SAMPLE PREPARATION}

The rock samples used in this study were obtained from the landslide zone of the Majiagou reservoir, in the Three Gorges area of Hubei Province, China, which is located at $31^{\circ} 01^{\prime} 08^{\prime \prime} \sim 31^{\circ} 01^{\prime} 17^{\prime \prime}$ north latitude and $110^{\circ} 41^{\prime} 48^{\prime \prime} \sim 110^{\circ} 42^{\prime} 10$ east longitude, as shown in Figure 1.

The rock sample looks dark red and is identified as iron- calcareous siltstone. Its density is $2.64 \mathrm{~g} / \mathrm{cm}^{3}$.
The crossed-polarized and plane-polarized images under a microscope are shown in Figure 2. The mineral composition mainly includes about $55 \%$ quartz, $5 \%$ mica, $30 \%$ calcite, $10 \%$ opaque iron mineral, etc.

Fifteen standard cylindrical specimens were used for uniaxial compression tests with diameter of $50 \mathrm{~mm}$ and height of $100 \mathrm{~mm}$. A total of 80 specimens with different shapes prepared for PLTs were divided into three groups: cylinder group, block group and irregular group. The cylindrical group consists of a number of cylindrical specimens with $50 \mathrm{~mm}$ in diameter and about $22 \mathrm{~mm}$ in height. The block specimens are 40-60 $\mathrm{mm}$ in length or width and 22- $25 \mathrm{~mm}$ in thickness. The irregular specimens were directly broken from the natural rock, with 40-60 mm in horizontal or vertical lengths and $22-25 \mathrm{~mm}$ in thickness. All the specimens are air-dried before the test. The representative rock samples are shown in Figure 3. 


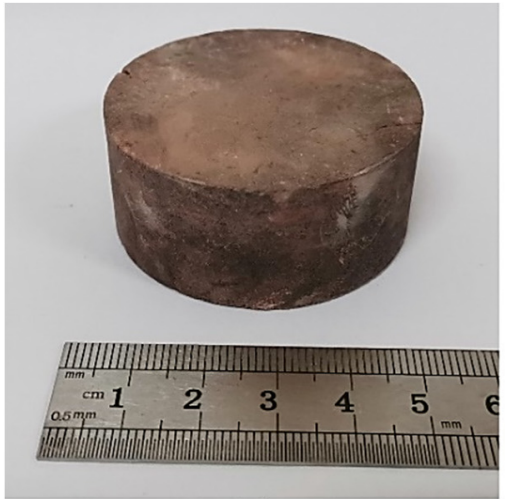

(a)

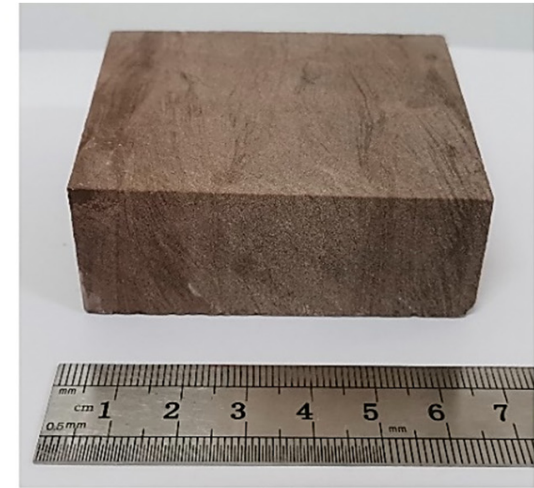

(b)

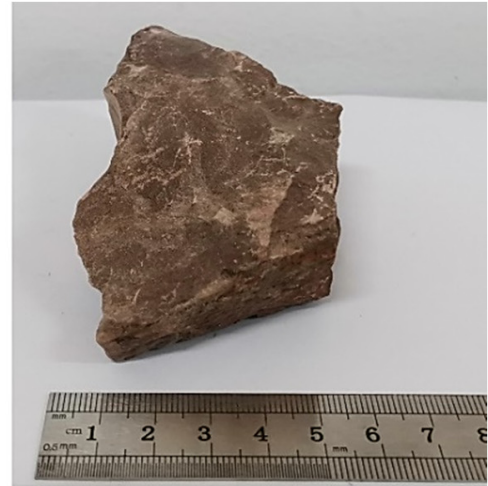

(c)

Fig. 3 Three types of specimens for point load tests. (a) Cylinder specimen. (b) Block specimen. (c) Irregular specimen.

\section{EXPERIMENTAL METHODOLOGY}

The uniaxial compressive tests were carried out using the experiment instrument shown in Figure 4 (a). The point load tests were realized by a portable rock point load equipment, in which the load was manually applied through a jack (see Fig. 4 (b)). The point load equipment is mainly composed of the loading system and digital display intelligent measurement and control system. The range of digital display system is about 0-100 kN. The digital display system can record the maximum load during the loading process. The conical platens have an angle of $60^{\circ}$ and a roundness radius of $5 \mathrm{~mm}$. During the test, the specimen was placed between the conical platens. Then a concentrated load was applied to the specimen through a manual jack until it was broken.

The $I_{s}$ value is calculated by the following equation:

$I_{s}=\frac{P}{D_{e}^{2}}$

where $\mathrm{I}_{\mathrm{S}}$ is the point load strength index value without correction, MPa; $\mathrm{P}$ is the failure load, $\mathrm{N} ; \mathrm{D}_{\mathrm{e}}$ is the equivalent diameter, $\mathrm{mm}$, which can be calculated by Eq. (2):

$D_{e}=\sqrt{\frac{4 W D}{\pi}}$

where $\mathrm{W}$ is the minimum cross-section width or the average width of two loading points, $\mathrm{mm}$; $\mathrm{D}$ is the distance between two loading points, $\mathrm{mm}$. Measurement methods of $\mathrm{W}$ and $\mathrm{D}$ are shown in Figure 5.

Table 1 UCS values for the siltstone specimens.

\begin{tabular}{lcccccccc}
\hline Specimen No. & P-1 & P-2 & P-3 & P-4 & P-5 & P-6 & P-7 & P-8 \\
\hline UCS/MPa & 80.12 & 52.31 & 45.12 & 53.22 & 70.39 & 70.36 & 73.52 & 49.32 \\
\hline Specimen No. & P-9 & P-10 & P-11 & P-12 & P-13 & P-14 & P-15 & \\
\hline UCS/MPa & 44.53 & 60.12 & 38.76 & 49.37 & 62.87 & 55.21 & 69.84 & \\
\hline Average/MPa & 58.34 & $\begin{array}{c}\text { Standard deviation } \\
/ \mathrm{MPa}\end{array}$ & 11.93 & & & & \\
\hline
\end{tabular}

The size and shape of the test specimens affect the point load strength index $I_{S}$ even the same kind of rock. So a correction factor is applied to obtain the $\mathrm{I}_{\mathrm{S}(50)}$, which is the point load strength index of standard specimens with a diameter of $50 \mathrm{~mm}$ under radial loading conditions (ISRM, 1985; ASTM, 2008). The calculation formulas are given by Eqs. (3) and (4).

$I_{S(50)}=F I_{S}$

$F=\left(\frac{D_{e}}{50}\right)^{0.45}$

where $\mathrm{F}$ is the size correction factor.

\section{RESULTS AND DISCUSSIONS}

\subsection{TEST RESULTS}

The results of uniaxial compression tests obtained from the above experiments are shown in Table 1. As demonstrated in laboratory test data, the UCS exhibit a significant dispersion. The reason is that the natural rock often contains micro-pores and cracks (Liu et al., 2018; Cai et al., 2004; Liu and Cai, 2020; Rong et al., 2013a; Rong et al., 2013b; Vavro et al., 2019; Wang and Cai, 2019).

According to the statistical analysis, the distributions of point load strength index $\left(I_{s}\right)$ value for different shapes of specimens are shown in Figures 6-8, which approximate a normal distribution. On the whole, the values of $I_{s}$ are scattered. At the confidence level of $95 \%$, the $\mathrm{I}_{\mathrm{s}}$ distribution interval and the confidence interval for different specimen shapes are given in Table 2. 


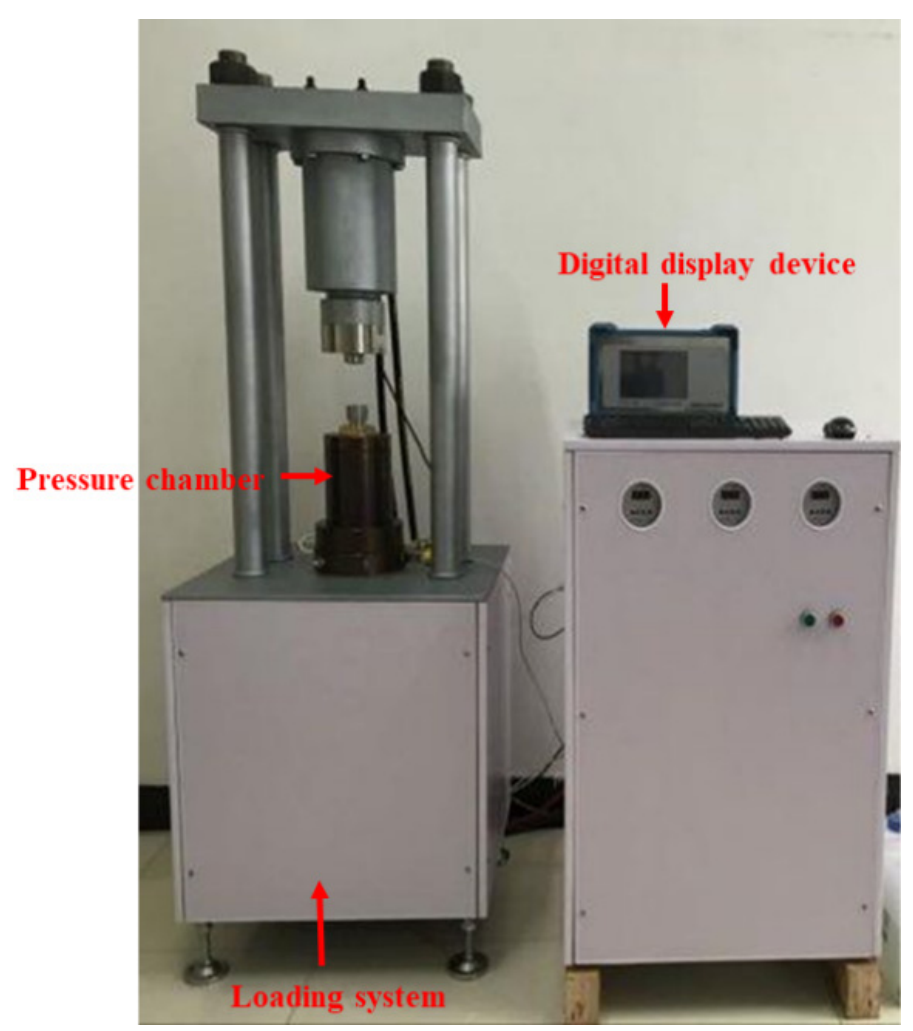

(a)

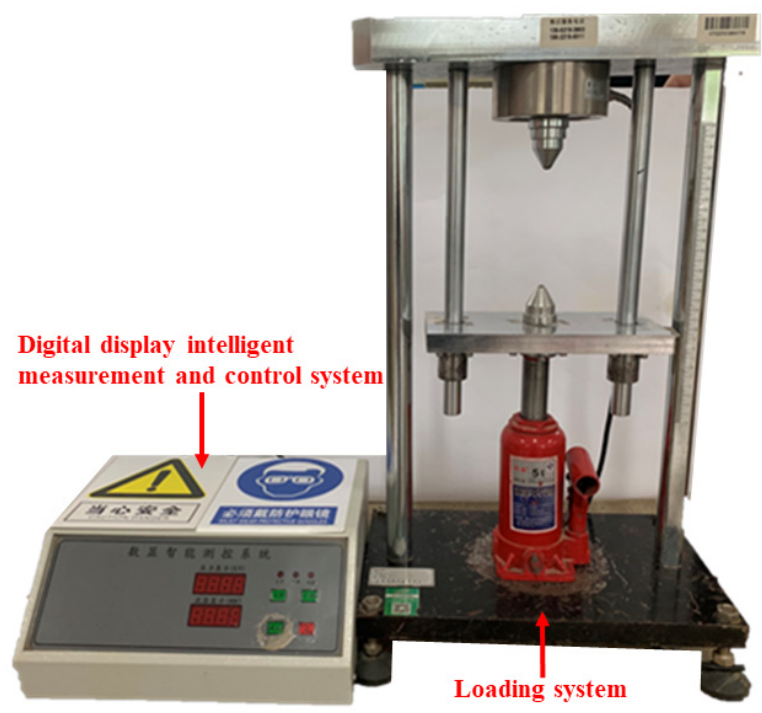

(b)

Fig. 4 Test equipment for uniaxial compressive tests and point load tests. (a) Uniaxial compression test equipment; (b) Point load tester YSD-7.

\subsection{CORRECTION OF PLSI}

The average values of corrected $\mathrm{I}_{\mathrm{s}(50)}$ with different shapes are given in Table 3 . It should be noted that the average value of $\mathrm{I}_{\mathrm{S}(50)}$ is calculated by deleting the two highest and lowest values from each group of tests, according to the ISRM (1985).

It can be seen that the mean $\mathrm{I}_{\mathrm{s}}$ of cylindrical specimens is $2.98 \mathrm{MPa}$, which is $0.19 \mathrm{MPa}$ larger than that of the irregular specimens, with a difference of over $7 \%$. However, the difference of $\mathrm{I}_{\mathrm{s}(50)}$ value between cylinder sample and block sample is $0.08 \mathrm{MPa}$ after being corrected according to Eqs. (3) and (4). The error is only $2.9 \%$, which meets the engineering requirements. In other words, the shape effect of specimens can be ignored after correction. 

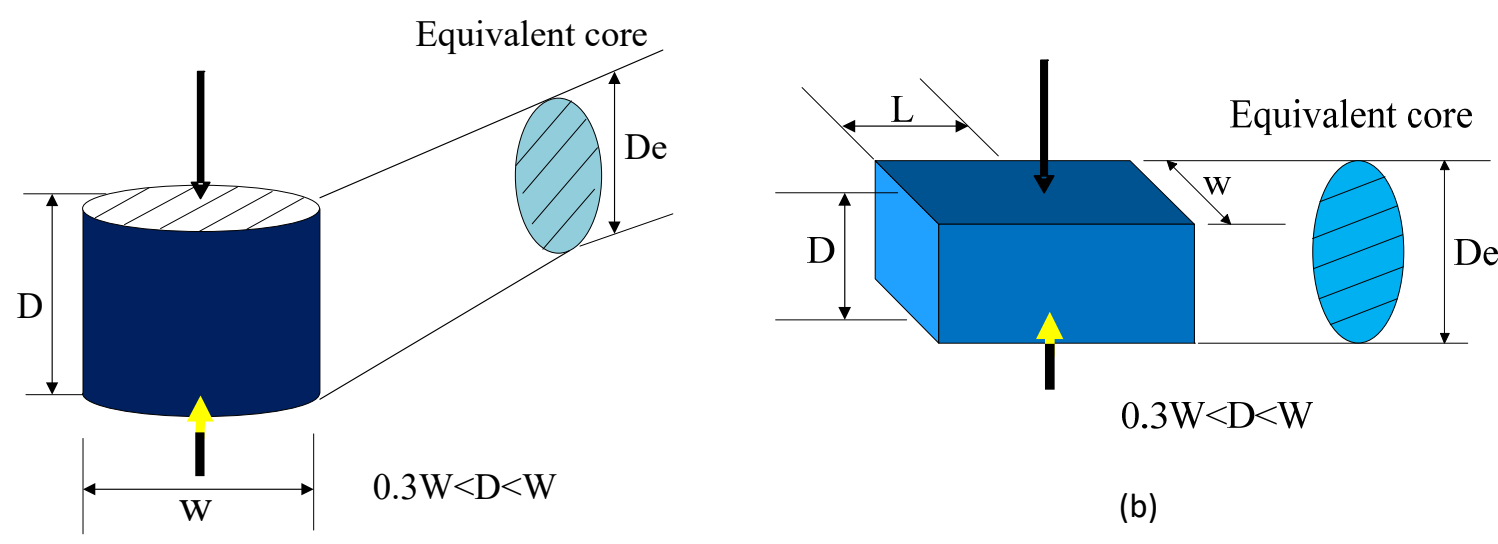

(a)

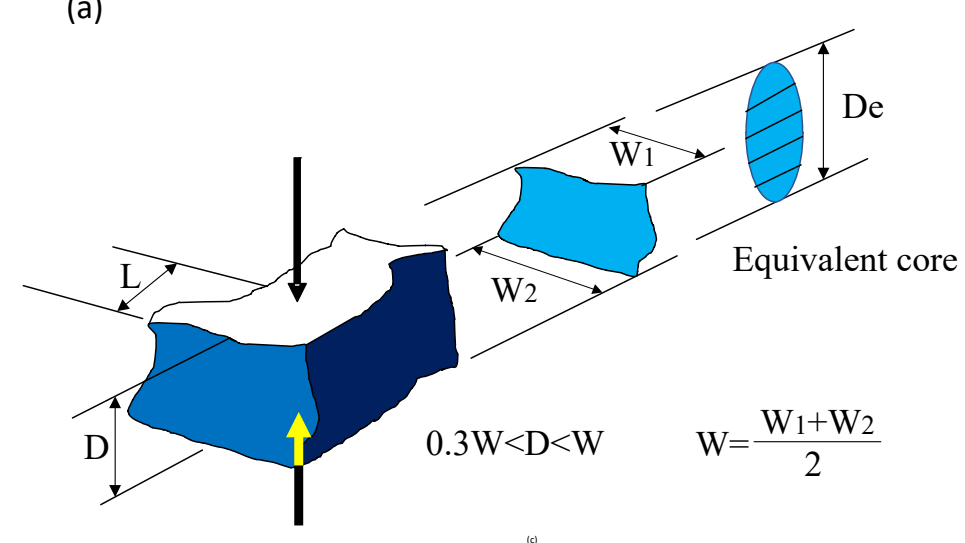

Fig. 5 Dimension measurement of the point load test. Modified from ISRM (1985).

Another method recommended by ISRM (1985) for obtaining reliable $\mathrm{I}_{\mathrm{S}(50)}$ values is adopted in this paper. The relation between $\mathrm{P}$ and $D_{e}^{2}$ of specimens with different shapes is fitted using a linear equation, which is shown in Figure 9. Based on the linear equation, the value of $\mathrm{P}_{50}$ corresponding to $D_{e}^{2}=2500$ $\mathrm{mm}^{2}\left(\mathrm{D}_{\mathrm{e}}=50 \mathrm{~mm}\right)$ can be obtained. Finally, the $\mathrm{I}_{\mathrm{s}(50)}$ can be calculated by

$\mathrm{I}_{\mathrm{S}(50)}=\mathrm{P}_{50} / 50^{2}$

From Figure 9, we can find $\mathrm{P}_{50}=6709.1 \mathrm{~N}$, $\mathrm{I}_{\mathrm{s}(50)}=\mathrm{P}_{50} / 50^{2}=2.68 \mathrm{MPa}$. This value is consistent with the average $I_{s(50)}$ calculated by Eqs. (3) and (4) including all specimens of different shapes (as shown in Table 3 ).

\subsection{RELATIONSHIP BETWEEN PLSI AND UCS}

Due to the differences in rock formation and tectonic environment, the physical and mechanical properties of rocks are significantly different. Moreover, the mineralogical composition, rock texture and structure, and cracks are also important factors causing the variability of mechanical properties (Liu et al., 2020). So there is no unique corresponding relationship between PLSI $\mathrm{I}_{\mathrm{s}(50)}$ and UCS to all rock types. But there is a strong statistical correlation between them. Some researchers have demonstrated that $I_{\mathrm{S}(50)}$ has a good linear correlation with the UCS for the specific type of rock and proposed various conversion formulas based on experimental results (Ghosh and Srivastava, 1991; Kahraman, 2001; Singh et al., 2012). It can be expressed as follows:

$\mathrm{UCS}=\mathrm{KI}_{\mathrm{s}(50)}$

where $\mathrm{K}$ is the conversion factor.

Many scholars have shown that the conversion factor between the $\mathrm{I}_{\mathrm{s}(50)}$ and UCS is related to rock types (Singh et al., 2012). However, even for the same type of rock type, the test results vary from region to region. Some representative results for sedimentary rock (sandstone or siltstone) are shown in Table 4. Based on the PLTs and UCS tests in this study, we can establish the relationship between the $\mathrm{I}_{\mathrm{s}(50)}$ and UCS for the red-bed siltstone.

The mean UCS of siltstone can be calculated from Table 1 as $\mathrm{UCS}=58.34 \mathrm{MPa}$. According to $\mathrm{I}_{\mathrm{s}(50)}$ values for the specimens with three shapes (as shown in Table 3), the UCS to $\mathrm{I}_{\mathrm{s}(50)}$ conversion factor are $22.10,21.45,21.85$ for cylinder, block and irregular specimens, respectively. If the influences of shape on PLSI are not considered, let $\mathrm{I}_{\mathrm{s}(50)}$ be $2.68 \mathrm{MPa}$, then the relationship between the $\mathrm{I}_{\mathrm{s}(50)}$ and UCS of the red-bed siltstone is given as follows:

$\mathrm{UCS}=21.77 \mathrm{I}_{\mathrm{s}(50)}$ 


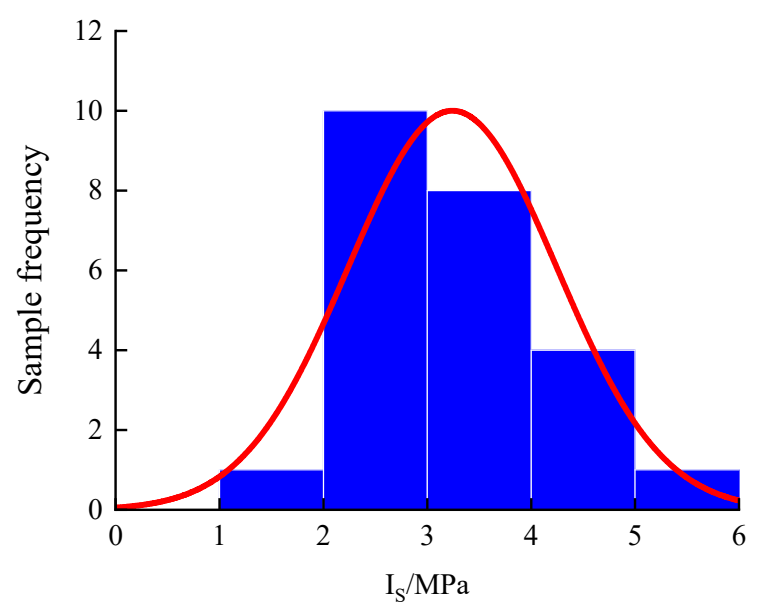

Fig. 6 Is distribution of cylinder specimens.

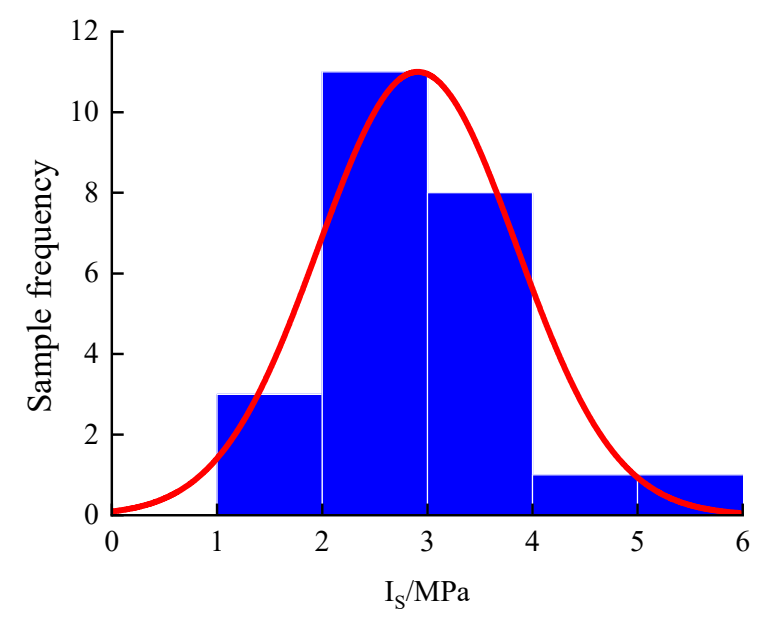

Fig. $7 \quad I_{S}$ distribution of block specimens.

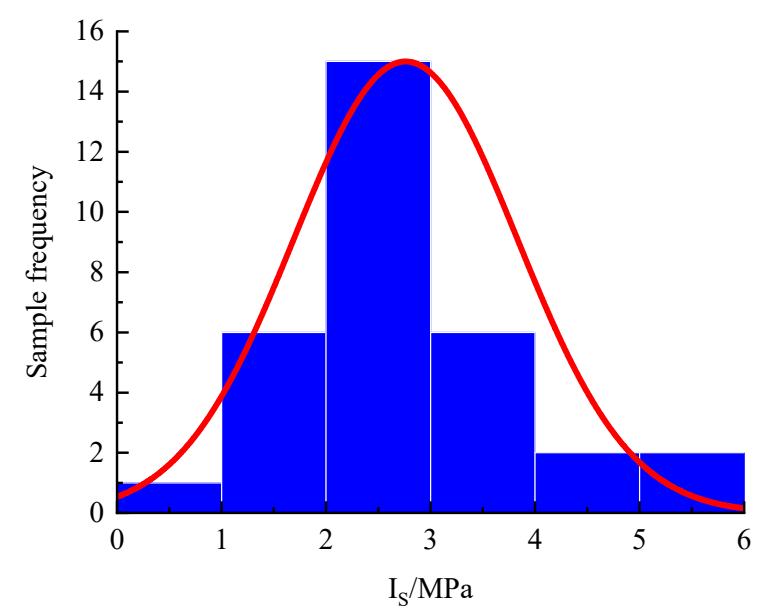

Fig. $8 \quad \mathrm{I}_{\mathrm{S}}$ distribution of irregular specimen.

\subsection{FAILURE MODES}

In the point load tests, only the fracture surface passes through both two platen loading points, the test will be considered valid (ISRM,1985; ASTM, 2008). In general, the specimens have different failure modes under point loading in the valid tests. Regardless of the initial shape and size of the specimen, it is observed two failure modes in the test, namely, two-piece and three- piece modes. The term 'two-piece mode' refers to a sample is broken into two pieces. Similarly, 'three-piece mode' represents a sample is split into three parts in the point load tests. Figure 10 shows representative specimens under point load tests.

Basu et al. (2013) have shown that failure along a single plane is the most common mode of failure in the case of granite and sandstone under point loading, and triple junction failure was also observed in a few specimens. According to Koohmishi et al. (2016), the railway ballast may have 'two-piece', 'three-piece' and 'four-piece' failure modes under point load. It is found that 'two-piece' is still the main mode of failure, and the 'four-piece' is observed only occasionally. In this study, the histogram distributions of failure modes are shown in Figure 11. It can be seen that the two- piece mode is the dominant failure mode, similar to the existing researches. Among them, cylindrical specimens have the biggest proportion of two-piece pattern, and the block and irregular specimens have about the same proportion of two-piece mode. On the whole, the failure modes of siltstone specimens with different shapes have little difference. Basu et al. (2013) have proposed that failure mode for ballast particles with higher strength was 'three- piece'. But there is no consistent conclusion with them in this experiment. The explicit relationship between the failure mode and the strength of samples needs to be further explored.

\section{CONCLUSION}

Based on the PLTs of the red-bed siltstone in the Three Gorges area, China, the following conclusions are obtained:

The PLSI obtained from different red-bed siltstone specimens exhibit approximately normal distribution. The average value of PLSI of the cylinder specimen is the largest, and that of the irregular specimen is the lowest. Moreover, the variance of PLSI of the irregular specimen is much larger than that of cylinder and block specimens. The shape of the specimen has an influence on the PLSI. The differences of PLSI with different shapes can be negligible after correction.

The average value of $I_{\mathrm{s}(50)}$ from formula correction is consistent with the values obtained by graphical method with all different shape specimens in consideration.

The failure specimens of red-bed siltstone under point load tests include two-piece and three-piece failure modes. The failure mode of the two pieces is about $80 \%$, and that of the three pieces is $20 \%$. Moreover, this ratio does not change significantly as the shape of the sample changes. This failure mode is likely to depend on the strength of specimens. The relationship between failure mode and the strength of the sample needs further study. 
Table 2 Analysis of experimental data.

\begin{tabular}{lccccc}
\hline & $\begin{array}{c}\text { Sample } \\
\text { number }\end{array}$ & Average/MPa & Variance/MPa & \multicolumn{2}{c}{ 95\% Confidence interval /MPa } \\
\cline { 5 - 6 } & & & & Lower bound & Upper bound \\
\hline Cylinder specimen IS & 24 & 3.04 & 1.01 & 2.40 & 3.45 \\
Block specimen IS & 24 & 2.91 & 0.89 & 2.31 & 3.24 \\
Irregular Specimen Is & 32 & 2.76 & 1.31 & 1.92 & 3.00 \\
\hline
\end{tabular}

Table 3 Point load strength of the specimens with different shapes.

\begin{tabular}{ccccc}
\hline Groups & Specimen shape & $\begin{array}{c}\text { Average } \mathrm{I}_{\mathrm{s}} / \\
\mathrm{MPa}\end{array}$ & $\begin{array}{c}\text { Average } \mathrm{I}_{\mathrm{s}(50)} / \\
\mathrm{MPa}\end{array}$ & $\begin{array}{c}\text { Average } \mathrm{I}_{\mathrm{s}(50)} / \mathrm{MPa} \\
\text { (including all three shapes) }\end{array}$ \\
\hline 1 & Cylinder & 2.98 & 2.64 & \\
2 & Block & 2.87 & 2.72 & 2.68 \\
3 & Irregular lump & 2.69 & 2.67 & \\
\hline
\end{tabular}

Table 4 The relationship between $\mathrm{I}_{\mathrm{S}(50)}$ and UCS.

\begin{tabular}{lll}
\hline Researcher & \multicolumn{1}{c}{ Rock type } & \multicolumn{1}{c}{ Equation } \\
\hline Bieniawski, 1975 & Sandstone & $\mathrm{UCS}=23.9 \mathrm{I}_{\mathrm{S}(50)}$ \\
ISRM, 1985 & $/$ & $\mathrm{UCS}=20-25 \mathrm{I}_{\mathrm{S}(50)}$ \\
Hawkins and Olver, 1986 & Sandstone & $\mathrm{UCS}=24.8 \mathrm{I}_{\mathrm{S}(50)}$ \\
Tsiambaos and Sabatakakis, 2004 & Limestones, marly limestones, & $\mathrm{UCS}=13 \mathrm{I}_{\mathrm{S}(50)}$ \\
Agustawijaya, 2007 & sandstones, and marlstones & $\mathrm{UCS}=13.4 \mathrm{I}_{\mathrm{S}(50)}$ \\
Singh et al., 2012 & Sandstone and siltstone & $\mathrm{UCS}=21.9 \mathrm{I}_{\mathrm{S}(50)}$ \\
Li and Wong, 2013 & Sandstone & $\mathrm{UCS}=20-21 \mathrm{I}_{\mathrm{S}(50)}$ \\
\hline
\end{tabular}

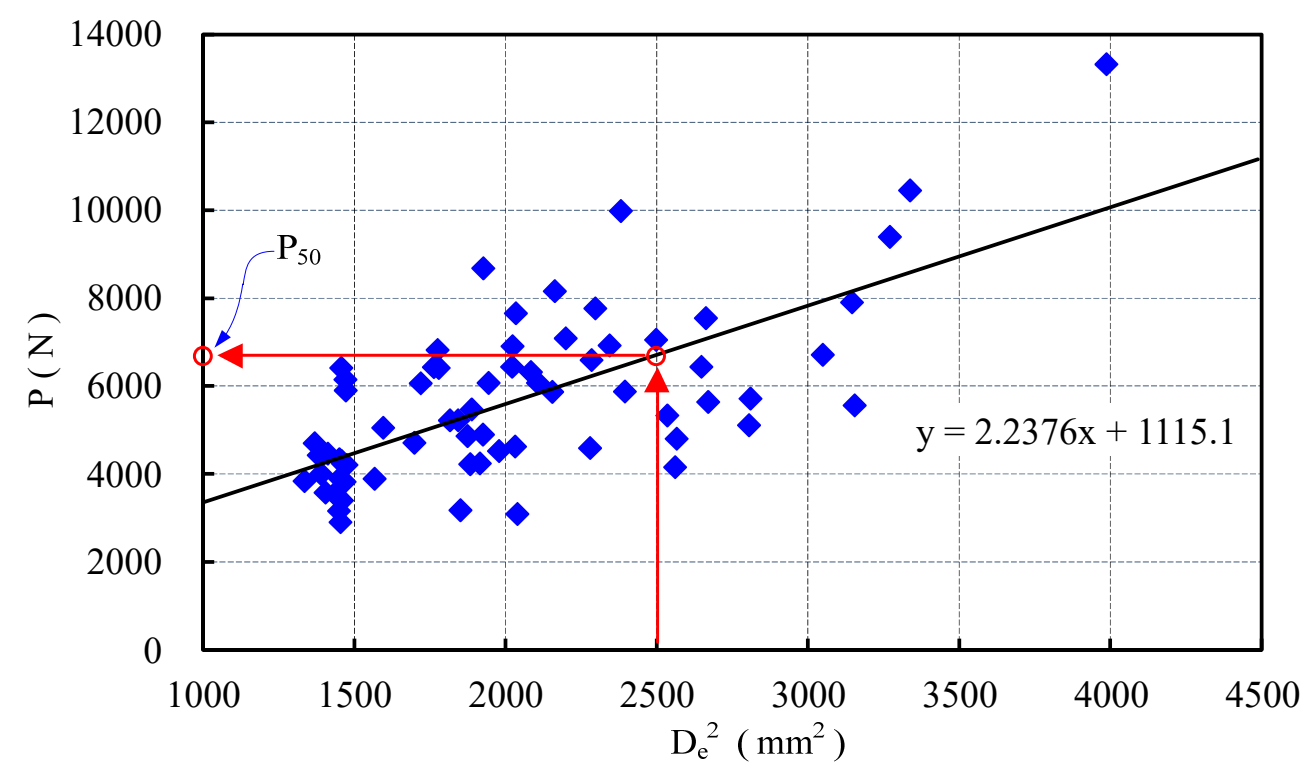

Fig. 9 The relation between load $\mathrm{P}$ and $D_{e}^{2}$.

Point load strength is an important parameter to determine the strength grade of rock. The results in this research have some guiding significance for evaluating the point load strength of rocks in the geological field survey of geological disasters in the Three Gorges reservoir area with different shapes and sizes. The relationship between $\mathrm{I}_{\mathrm{s}(50)}$ and UCS of the red-bed siltstone can be helpful in the assessment of the weathering and deterioration of rocks.

\section{ACKNOWLEDGMENTS}

The work reported in this study has received financial support from the National Natural Science Foundation of China (Nos.51579063 and 52009024), the Natural Science Foundation of Hubei Provincial Department of Education of China (No. D20191201), the Applied Basic Research Projects in Yichang City of China (No. A19-302-09), Anhui Natural Science Youth Fund (No. 1908085QE216) and Innovation and entrepreneurship funds for returnees of Hefei. These supports are gratefully acknowledged. 

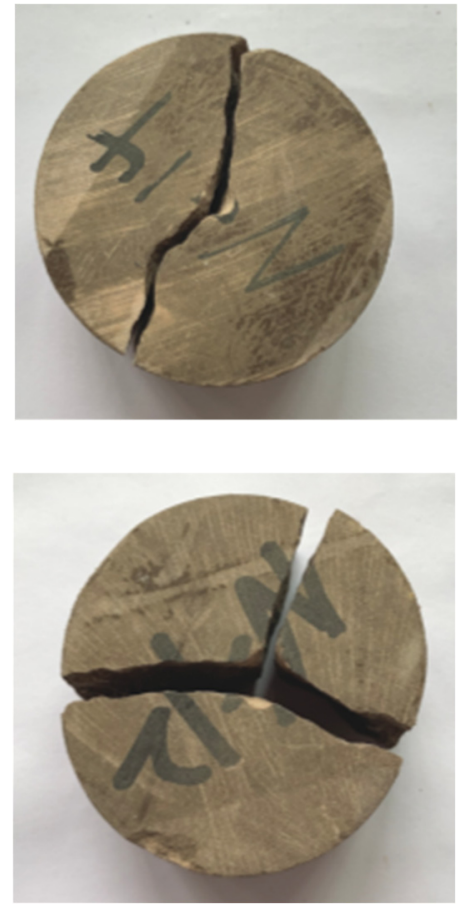

(a) Cylinder

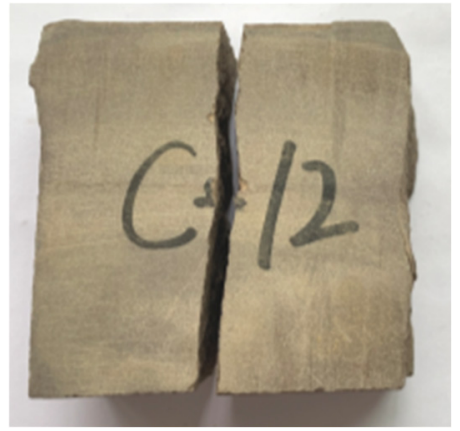

Two-piece failure modes

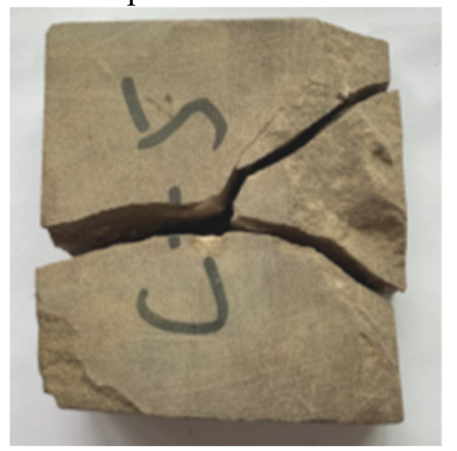

Three-piece failure modes

(b) Block
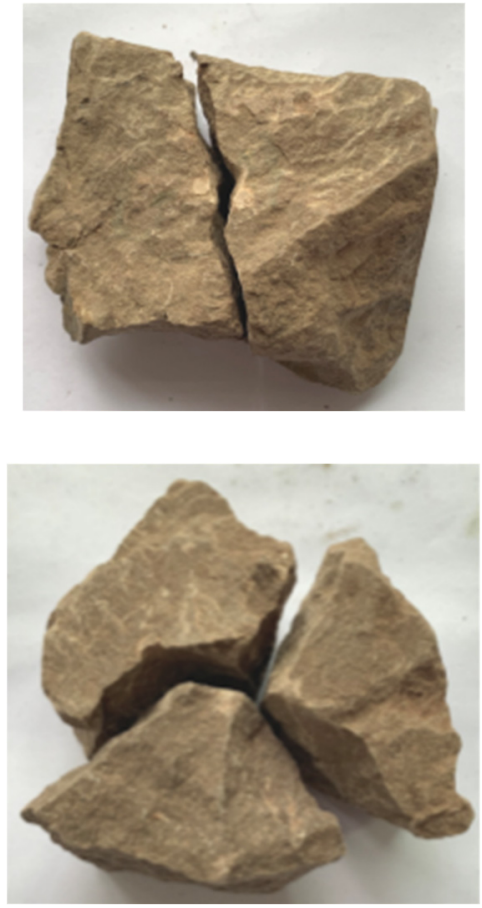

(c) Irregular specimen

Fig. 10 Failure modes of specimens under point load tests.

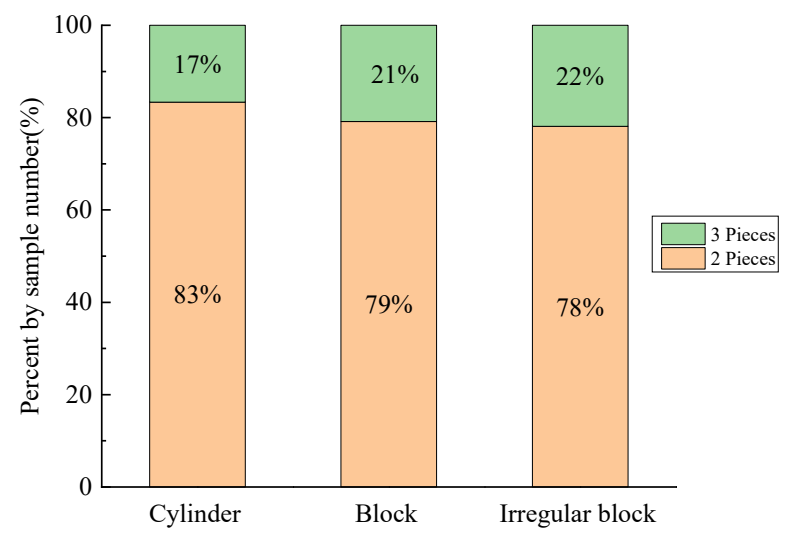

Fig. 11 Histogram distribution of failure modes.

\section{REFERENCES}

Akbay, D. and Altindag, R.: 2018, Determination of the errors arising from apparatus and operator during applying the point load index. In ISRM Regional Symposium-EUROCK 2018-016.

Akbay, D. and Altindag, R.: 2020, Reliability and evaluation of point load index values obtained from different testing devices. J. S. Afr. I. Min. Metall., 20, 3, 181190. DOI: $10.17159 / 2411-9717 / 759 / 2020$

Agustawijaya, D.S.: 2007, The uniaxial compressive strength of soft rock. Civ. Eng. Dimen., 9, 1, 9-14. DOI: 10.9744/ced.9.1.pp.\%209-14

ASTM D5731-08: 2008, Standard test method for determination of the point load strength index of rock and application to rock strength classifications. American Society for Testing and Materials, West Conshohocken, PA. 1-11.

Basu, A., Mishra, D.A. and Roychowdhury, K.: 2013, Rock failure modes under uniaxial compression, Brazilian, and point load tests. Bull. Eng. Geol. Environ., 72, 34, 457-475. DOI: 10.1007/s10064-013-0505-4

Bieniawski, Z.T.: 1975, The point-load test in geotechnical practice. Eng. Geol., 9, 1, 1-11. DOI: $10.1016 / 0013-7952(75) 90024-1$

Broch, E. and Franklin, J.A.: 1972, The point-load strength test. Int. J. Rock. Mech. Min. Sci, 9, 6, 669-676. DOI: 10.1016/0148-9062(72)90030-7

Cai, M., Kaiser, P.K., Tasaka, Y., Maejima, T., Morioka, H. and Minami, M.: 2004, Generalized crack initiation and crack damage stress thresholds of brittle rock masses near underground excavations. Int. J. Rock Mech. Min. Sci., 41, 5, 833-847. DOI: 10.1016/j.ijrmms.2004.02.001

Eberhardt, E., Stimpson, B. and Stead, D.: 1999, Effects of grain size on the initiation and propagation thresholds of stress-induced brittle fractures. Rock Mech. Rock Eng., 32, 2, 81-99. DOI: 10.1007/s006030050026

Emir, E. and Beyhan, S.: 2016, Appraisal of the effect of humidity on triaxial compressive strength of marl material by numerical modeling, Acta Geodyn. Geomater, 13, 1, 103-118. DOI: 10.13168/AGG.2015.0045

Hawkins, A.B. and Olver, J.A.G.: 1986, Point load tests: correlation factor and contractual use. An example from the Corallian at Weymouth. Geological Society, London, Eng. Geol. Spec. Publ., 2, 269-271. DOI: 10.1144/GSL.1986.002.01.48 
ISRM: 1985, Suggested method for determining point load strength. Int. J. Rock. Mech. Min. Sci., 22, 2, 51-60. DOI: 10.1016/0148-9062(85)92327-7

Kahraman, S.: 2001, Evaluation of simple methods for assessing the uniaxial compressive strength of rock. Int. J. Rock. Mech. Min. Sci., 38, 7, 981-994. DOI: $10.1016 / \mathrm{S} 1365-1609(01) 00039-9$

Koohmishi, M. and Palassi, M.: 2016, Evaluation of the strength of railway ballast using point load test for various size fractions and particle shapes. Rock Mech. Rock Eng., 49, 7, 2655-2664.

DOI: $10.1007 / \mathrm{s} 00603-016-0914-3$

Li, D. and Wong, L.N.Y.: 2013, Point load test on metasedimentary rocks and correlation to UCS and BTS. Rock Mech. Rock Eng., 46, 4, 889-896. DOI: $10.1007 / \mathrm{s} 00603-012-0299-\mathrm{x}$

Liu, G. and Cai, M.: 2020, Modeling time-dependent deformation behavior of brittle rock using grain-based stress corrosion method. Comput. Geotech., 118, 103323. DOI: 10.1016/j.compgeo.2019.103323

Liu, G., Cai, M. and Huang, M.: 2018, Mechanical properties of brittle rock governed by micro-geometric heterogeneity. Comput. Geotech., 104, 358-372. DOI: 10.1016/j.compgeo.2017.11.013

Liu, G., Peng, J., Zhang, Z., Wang, Z. and Yang, Y.: 2020, Numerical investigation of fluid-driven crack propagation and coalescence in granite specimen with two pre-existing flaws. J. Nat. Gas. Sci. Eng., 75, 103132. DOI: $10.1016 /$ j.jngse.2019.103132

Masoumi, H., Roshan, H., Hedayat, A. and Hagan, P.C.: 2018, Scale-size dependency of intact rock under point-load and indirect tensile brazilian testing. Int. J. Geomech, 18, 3, 04018006.

DOI: 10.1061/(ASCE)GM.1943-5622.0001103

Panek, L.A. and Fannon, T.A.: 1992, Size and shape effects in point load tests of irregular rock fragments. Rock Mech. Rock Eng., 25, 2, 109-140.

DOI: $10.1007 / \mathrm{BF} 01040515$

Peng, J., Wong, L.N.Y., Liu, G. and Teh, C.I.: 2019, Influence of initial micro-crack damage on strength and micro-cracking behavior of an intrusive crystalline rock. Bull. Eng. Geol. Environ., 78, 4, 2957-2971. DOI: 10.1007/s10064-018-1317-3

Qin, Z., Li, T., Li, Q., Chen, G. and Cao, B.: 2019, Mechanism of rock burst based on energy dissipation theory and its applications in erosin zone. Acta Geodyn. Geomater., 16, 2(194), 119-130.

DOI: 10.13168/AGG.2019.0009

Rong, G., Liu, G., Hou, D. and Zhou, C.B.: 2013b, Effect of particle shape on mechanical behaviors of rocks: a numerical study using clumped particle model. Sci. World J., 589215. DOI: 10.1155/2013/589215

Rong, G., Peng, J., Wang, X., Liu, G. and Hou, D.: 2013a, Formation mechanism of deep cracks in the left bank slope of Jinping-i hydropower station. Disaster Adv., $6,3,4-11$.

Singh, T.N., Kainthola, A. and Venkatesh, A.: 2012, Correlation between point load index and uniaxial compressive strength for different rock types. Rock Mech. Rock Eng., 45, 2, 259-264.

DOI: $10.1007 / \mathrm{s} 00603-011-0192-\mathrm{z}$

Tsiambaos, G. and Sabatakakis, N.: 2004, Considerations on strength of intact sedimentary rocks. Eng. Geol., 72, 34, 261-73. DOI: 10.1016/j.enggeo.2003.10.001

Turk, N. and Dearman, W.R.: 1985, Improvements in the determination of point load strength. Bull. Int. Assoc. Eng. Geol., 31, 1, 137-142.

DOI: $10.1007 / \mathrm{BF} 02594757$
Vavro, L., Malíková, L., Frantík, P., Kubeš, P., Keršner, Z. and Vavro, M.: 2019, An advanced assessment of mechanical fracture parameters of sandstones depending on the internal rock texture features. Acta Geodyn. Geomater., 16, 2(194), 157-168. DOI: 10.13168/AGG.2019.0013

Wang, X. and Cai, M.: 2018, Modeling of brittle rock failure considering inter-and intra-grain contact failures. Comput. Geotech., 101, 224-244. DOI: $10.1016 /$ j.compgeo.2018.04.016

Wang, X. and Cai, M.: 2019, A comprehensive parametric study of grain-based models for rock failure process simulation. Int. J. Rock. Mech. Min. Sci., 115, 60-76. DOI: 10.1016/j.ijrmms. 2019.01.008

Wang, F.W., Zhang, Y.M., Huo, Z.T., Matsumoto, T. and Huang, B.L.: 2004, The July 14, 2003 Qianjiangping landslide, Three Gorges Reservoir, China. Landslides, 1,2,157-162. DOI: 10.1007/s10346-004-0020-6

Wong, R.H.C., Chau, K.T., Yin, J.H., Lai, D.T.W. and Zhao, G.S.: 2017, Uniaxial compressive strength and point load index of volcanic irregular lumps. Int. J. Rock. Mech. Min. Sci., 93, 307-315. DOI: $10.1016 /$ j.ijrmms.2017.02.010

Yin, J.H., Wong, R.H.C., Chau, K.T., Lai, D.T.W. and Zhao, G.S.: 2017, Point load strength index of granitic irregular lumps: size correction and correlation with uniaxial compressive strength. Tunn. Undergr. Sp. Tech., 70, 388-399. DOI: 10.1016/j.tust.2017.09.011

Zhang, M., Yin, Y. and Huang, B.L.: 2015, Mechanisms of rainfall-induced landslides in gently inclined red beds in the eastern Sichuan Basin, SW China. Landslides, 12, 5, 973-983. DOI: 10.1007/s10346-015-0611-4 